\title{
Review \\ Multiple Endocrine Neoplasia in Childhood: An Update on Diagnosis, Screening, Management and Treatment
}

\author{
Marianne Jacob ${ }^{1}$, Dustin Rowland ${ }^{2}$, Oksana Lekarev ${ }^{1}$ and Berrin Ergun-Longmire ${ }^{2, *}$ \\ 1 Division of Pediatric Endocrinology, Department of Pediatrics, Weill Cornell Medicine, \\ NewYork-Presbyterian Hospital, 505 East 70th Street, New York, NY 10021, USA; maj9191@nyp.org (M.J.); \\ ok19003@med.cornell.edu (O.L.) \\ 2 Department of Pediatric \& Adolescent Medicine, Homer Stryker M.D. School of Medicine, \\ Western Michigan University, 1000 Oakland Drive, Kalamazoo, MI 49008, USA; \\ dustin.rowland@med.wmich.edu \\ * Correspondence: berrin.ergun-longmire@med.wmich.edu
}

check for updates

Citation: Jacob, M.; Rowland, D.; Lekarev, O.; Ergun-Longmire, B. Multiple Endocrine Neoplasia in Childhood: An Update on Diagnosis, Screening, Management and Treatment. Endocrines 2022, 3, 76-91. https://doi.org/10.3390/ endocrines3010007

Academic Editor: Yukihiro Hasegawa

Received: 10 January 2022 Accepted: 8 February 2022 Published: 17 February 2022

Publisher's Note: MDPI stays neutral with regard to jurisdictional claims in published maps and institutional affiliations.

Copyright: (C) 2022 by the authors. Licensee MDPI, Basel, Switzerland. This article is an open access article distributed under the terms and conditions of the Creative Commons Attribution (CC BY) license (https:// creativecommons.org/licenses/by/ $4.0 /)$.

\begin{abstract}
Multiple endocrine neoplasia (MEN) is a group of heterogenous syndromes characterized by the occurrence of two or more endocrine gland tumors in a patient or related individuals in the same family. They are inherited in an autosomal dominant fashion and are highly penetrant. There are three types of MEN syndromes: MEN type 1 (MEN1), MEN type 2 (MEN2), and MEN type 4 (MEN4). MEN2 is further divided into MEN2A, MEN2B (formerly known MEN3), and familial medullary thyroid carcinoma (FMTC). Although MEN syndromes are rare, it is crucial to identify individuals at risk for potentially life-threatening neoplasias. This review article provides an update on each MEN syndrome, its genetics, diagnosis, and management in children.
\end{abstract}

Keywords: multiple endocrine neoplasia; MEN1; MEN2A; MEN2B; MEN4; familial medullary thyroid carcinoma

\section{Introduction}

Multiple endocrine neoplasia (MEN) is a rare group of inherited disorders with the occurrence of two or more endocrine gland tumors in an individual or related individuals in the same family [1]. These disorders are inherited in an autosomal dominant fashion and are highly penetrant. They can appear at any age, and symptoms vary depending on which endocrine and non-endocrine organs are affected. There are three types of MEN syndromes: MEN type 1 (MEN1), MEN type 2 (MEN2), and MEN type 4 (MEN4). MEN1 (Wermer's syndrome) mainly affects the parathyroid, pituitary, and pancreas [2]. MEN1 is caused by germline heterozygous loss-of-function mutations in the tumor suppressor gene MEN1 [1]. MEN2 is further divided into MEN2A, MEN2B (formerly known MEN3), and familial medullary thyroid carcinoma (FMTC). Thyroid, parathyroid, and adrenal glands are the principal glands involved in MEN2 syndromes. According to the latest American Thyroid Association (ATA) 2015 guidelines, FMTC is recognized as a variant of MEN2A with decreasing penetrance of hyperparathyroidism and pheochromocytoma [3]. MEN2 occurs due to mutations in the tyrosine kinase receptor encoded by the REarranged during Transfection (RET) proto-oncogene on 10q11.2 [4].

MEN4 is the most recent member of the MEN syndromes caused by mutations in the putative tumor suppressor gene, a cyclin-dependent kinase inhibitor (CDNK1B) [5]. Similar to MEN1, affected patients have primary hyperparathyroidism and pituitary adenoma (the most common phenotype), pancreatic neuroendocrine tumors in association with gonadal, adrenal, renal, and thyroid tumors [6].

In this review, we provided an update on MEN syndromes and their genetics as well as guidelines for screening and management considerations in children. Identifying at-risk individuals is crucial in preventing and treating potentially life-threatening endocrine and non-endocrine neoplasias, thereby improving and prolonging life. 


\section{Multiple Endocrine Neoplasia Type 1 (MEN1)}

\subsection{Clinical Presentation}

MEN1, also known as Wermer's syndrome, is characterized by tumors of the parathyroid glands, anterior pituitary, and gastro-entero-pancreatic system. The worldwide prevalence is 3-20 in 100,000 individuals; this variation in prevalence is theorized to be due to founder effects (Table 1) [7-10]. The syndrome is autosomal dominant with an extremely high penetrance- $50 \%$ of cases will manifest characteristic tumors by age 20 and $95 \%$ by age 40 [8]. Both hereditary (familial) and non-hereditary (sporadic) forms exist [7,9].

Table 1. MEN syndrome types and associated clinical and genetic characteristics in children.

\begin{tabular}{|c|c|c|c|c|}
\hline & Prevalence & Clinical Features & $\begin{array}{c}\text { Youngest Age of } \\
\text { Presentation (Years) }\end{array}$ & $\begin{array}{c}\text { Genes and } \\
\text { Common Variants }\end{array}$ \\
\hline MEN 1 & $3-20: 100,000$ & $\begin{array}{l}\text { Parathyroid adenoma } \\
\text { (most common) } \\
\text { Pancreatic neuroendocrine tumors } \\
\text { - } \quad \text { Gastrinoma } \\
\text { - } \quad \text { Insulinoma } \\
\text { - } \quad \text { Glucagonoma } \\
\text { - } \quad \text { VIPoma } \\
\text { Pituitary adenomas } \\
\text { - } \quad \text { Prolactinoma (most common) } \\
\text { - } \quad \text { Somatotrophinoma } \\
\text { - } \quad \text { Corticotrophinoma } \\
\text { Associated tumors } \\
\text { (less common): } \\
\text { Endocrine: } \\
\text { - } \quad \text { Adrenocortical } \\
\text { - } \quad \text { Thymic and bronchial carcinoid } \\
\text { Non-endocrine: } \\
\text { - } \quad \text { Angiofibroma } \\
\text { - } \quad \text { Collagenoma } \\
\text { - } \quad \text { Lipoma }\end{array}$ & $\begin{array}{l}\text { Rare; insulinoma } \\
\text { reported in a } \\
5 \text { year old child }\end{array}$ & MEN1 \\
\hline $\begin{array}{l}\text { MEN } 2 \\
\text { Type 2A }\end{array}$ & $1: 36,000-1: 200,000$ & $\begin{array}{l}\text { MTC } \\
\text { Pheochromocytoma } \\
\text { Parathyroid adenoma }\end{array}$ & $\begin{array}{l}2 \\
8 \\
2\end{array}$ & $\begin{array}{c}\text { RET } \\
\text { Exons } 10 \\
\text { (codon 634) and } 11\end{array}$ \\
\hline Type 2B & $1: 600,000-1: 4,000,000$ & $\begin{array}{l}\text { MTC } \\
\text { Pheochromocytoma } \\
\text { Intestinal ganglioneuroma } \\
\text { Mucosal neuroma } \\
\text { Marfanoid habitus }\end{array}$ & $\begin{array}{l}\text { Infancy } \\
12 \\
\text { Infancy }\end{array}$ & $\begin{array}{c}\text { Exon } 16 \\
\text { (codon 918) }\end{array}$ \\
\hline MEN 4 & Unknown & $\begin{array}{l}\text { Parathyroid hyperplasia } \\
\text { and adenoma }\end{array}$ & $\begin{array}{l}\text { Third decade } \\
\text { of life }\end{array}$ & $C D K N 1 B$ \\
\hline
\end{tabular}

RET = REarranged during Transfection; MTC = medullary thyroid carcinoma.

The most common manifestation of MEN1 in children is primary hyperparathyroidism (PHPT) due to parathyroid gland hyperplasia; up to $75 \%$ of affected children will develop PHPT, most commonly after age 10 [11]. By age 50, 95\% of MEN1 patients will have developed PHPT; onset is typically at 20 to 25 years of age $[2,12,13]$. Prevalence is similar in both males and females [14,15]. MEN1-associated PHPT occurs about 30 years earlier than sporadic forms of PHPT. Moreover, MEN1-associated PHPT presents with diffuse parathyroid hyperplasia versus the single adenomas characteristic of sporadic PHPT. PHPT 
is typically asymptomatic, even if hypercalcemia is present. If hypercalcemia does become symptomatic, an affected child can present with malaise, polyuria, polydipsia, or constipation. The degree of hypercalcemia is rarely severe enough to lead to crisis $[10,14]$.

Pancreatic islet cell tumors, also referred to as pancreatic neuroendocrine tumors (NETs), are the second most frequent manifestation of MEN1 [14]. These tumors occur in $70-80 \%$ of patients with onset most often after the age of 40 [10]. In order of decreasing penetrance, NETs include gastrinomas (40\%), non-functioning pancreatic polypeptide-secreting tumors (PPomas), insulinoma, glucagonomas, and vasoactive intestinal polypeptidomas (VIPomas) [14]. Pancreatic tumors have significant potential for malignancy and are therefore important to screen for during evaluation in patients with MEN1.

Gastrinomas are gastrin-secreting tumors that are characterized by excessive gastric acid production and recurrent peptic ulcers that occur in individuals older than 30 years of age [14]. They are rare in children but are typically aggressive if present $[11,16]$. Gastrinomas occur three times more commonly in the duodenum than in the pancreas [17]. However, those found in the pancreas have a $50 \%$ incidence of liver metastasis [18]. The extent of the liver involvement due to a gastrinoma is the most important predictor of survival [19]. Zollinger-Ellison Syndrome (ZES) is a syndrome of gastric acid hypersecretion caused by gastrinomas and occurs in approximately $50 \%$ of patients with MEN1. Diagnosis may be delayed up to 3 to 5 years [20]. Individuals may present with signs and symptoms of peptic ulcer disease, gastroesophageal reflux, and secretory diarrhea. Severe ulcers resulting from gastric acid hypersecretion are one of the most common causes of MEN1-related premature death [12]. Hypercalcemia from parathyroid adenomas can further increase serum gastrin levels and thus worsen symptoms [21]. The onset of ZES is more likely to occur after PHPT is diagnosed [20]. Diagnosis is established by identifying serum gastrin levels greater than 10 times the upper limit of normal in the setting of increased basal gastric acid secretion [14].

Insulinomas are insulin-secreting tumors of the pancreatic beta-cells and are the second most common NET to occur in those with MEN1 (incidence of approximately $10 \%$ ) [14]. They are most often the first manifestation of MEN1 in individuals less than 20 years old [2,11]. Insulin hypersecretion leads to hypoglycemia, which at times can be severe, and is often pronounced during times of fasting or exertion [14]. Individuals will clinically present with symptoms such as weakness, blurry vision, or even seizures. Biochemical studies reveal inappropriately elevated insulin and c-peptide levels in the setting of hypoglycemia.

Several MEN1-associated neuroendocrine tumors, which have been noted to occur in adults, have not been well-described in children. Glucagon-secreting pancreatic tumors, also known as glucagonomas, arise from alpha-cells of the pancreas. They occur in less than 3\% of adults with MEN1 [14]. Interestingly, MEN1 mutations are discovered in $60 \%$ of sporadic glucagonomas [17]. Clinically, patients may present with a rash (necrotizing migratory erythema), weight loss, or hyperglycemia. Individuals with glucagonoma also have an increased risk of venous thromboembolism [22]. Glucagonomas may be found incidentally on routine imaging. Another rare MEN1-associated tumor is VIPoma, which presents in less than $1 \%$ of patients and is characterized by profuse secretory diarrhea, hypokalemia, and achlorhydria [14]. Diagnosis may be established by noting fasting stool volumes of 0.5 to $1.0 \mathrm{~L}$ per day in addition to a markedly elevated plasma VIP concentration. Aside from alpha and beta islet cell tumors, delta cells (somatostatin-producing cells) may also participate in hormone hypersecretion. However, hypersecretion of somatostatin is rare.

Non-functioning NETs are tumors that are not associated with a particular syndrome and do not present clinically, except in the case of significant mass effect. They have a frequency of 55\% in those with MEN1 and are most often located within the pancreas $[9,23]$. Non-functioning NETs have been discovered in patients less than 15 years of age and as young as age $10[24,25]$. 
Pituitary adenomas are the third-most common tumors in adults with MEN1 and occur in approximately 30 to $50 \%$ of individuals, with prolactinomas being the most common $(60 \%)[9,11,14,16]$. In children, pituitary adenomas occur second in frequency $(34 \%)$ of MEN1 tumors and occur as young as 5 years of age $[11,16,26]$. In sporadic pediatric prolactinoma cases, up to $6.5 \%$ are associated with previously undiagnosed MEN-1 [27]. Pituitary adenomas are more frequent in females with a 3.2:1 female to male ratio during childhood [14]. However, in both children and adults, males present with more macroadenomas, which are also more aggressive than those found in females $[11,28]$. Other anterior pituitary tumors include somatotrophinomas (growth hormone-secreting; 25\%) and corticotrophinomas (adrenocorticotropic hormone-secreting; 5\%) with the remainder being non-functioning adenomas [14,29]. Clinical symptoms depend on the hormones secreted in addition to tumor size, which can cause compressive effects leading to vision loss; malignancy is highly unusual [9].

Affected individuals may also develop other endocrine tumors, including adrenocortical tumors, bronchial and thymic carcinoid tumors, as well as non-endocrine tumors such as collagenomas, facial angiofibromas, and lipomas.

\subsection{Diagnosis}

Diagnosis of MEN1 can be made on clinical, familial, or genetic grounds [14]. A clinical diagnosis is suspected if there are two or more MEN1-associated tumors. However, expression of the MEN1 phenotype is age-dependent. As such, clinical manifestations may not be noted prior to age 5, as clinical features are rare before this age [14]. For familial diagnosis, the patient must have a MEN1-associated tumor and a first-degree relative with MEN1. Identification of a germline MEN1 mutation secures a genetic diagnosis and is the primary means by which children and adolescents are diagnosed [16]. In relatives of MEN1-affected patients, genetic testing should be completed before age 5 since children are often clinically asymptomatic [14]. In approximately 5-25\% of individuals with a clinical diagnosis of MEN1, a genetic mutation cannot be found [30,31]. This is described as a phenocopy. MEN1 phenocopies are common and can be a confounder for genetic testing. Those with a mutation-negative MEN1 phenotype tend to develop MEN1 characteristics, such as PHPT and pituitary adenoma, at more advanced ages [31,32]. Given that MEN1 mutation-positive and mutation-negative individuals have differing clinical courses, those who are mutation-negative are sometimes considered to have a separate MEN1-like syndrome [32]. Population analysis indicates that the life expectancy of an individual with mutation-negative MEN1 is not altered by their diagnosis [31]. However, in patients with a confirmed MEN1 mutation, they present with a reduced life expectancy averaging 63 years of age, often due to death from gastroenteropancreatic malignancy [12].

\subsection{Genetics}

MEN1 is caused by a germline mutation in the MEN1 gene, which is found at locus $11 q 13$ [16]. The gene consists of 10 exons that encode a $2.8 \mathrm{kB}$ mRNA segment, which is then translated into a 610 amino acid protein called menin [12,17]. There are more than 1200 reported mutations that result in MEN1, 75\% of which result in the loss of function of menin [8]. Mutations in both the coding and noncoding regions of MEN1 have been implicated in MEN1 pathogenesis [12]. Identification of MEN1 index cases is generally through the discovery of MEN1-related tumors, followed by confirmation of MEN1 mutation via genetic testing [9]. Although such a wide variety of MEN1 mutations exist, MEN1 does not have any known genotype-phenotype correlation. Lack of a strong genotype-phenotype correlation, even within one family, is likely due to the structure of menin itself, as all regions of this protein are essential for proper function [17].

Though a genotype-phenotype correlation is not well-recognized in MEN1, studies have explored potential epigenetic changes in menin that may be responsible for MEN1 phenocopies, especially in mutation-negative individuals. MicroRNAs (miRNAs) regulate gene expression and several have been found to downregulate the expression of menin 
such as miR-24, miR-29b and miR-762 [33]. Specific miRNAs have been found to be key in the development of insulinomas and parathyroid adenomas [34,35]. In evaluating both MEN1-related and sporadic NETs, hypermethylation of CpG regions on DNA has also been frequently noted [36]. As epigenetic changes are reversible, further study may ultimately help discover potential therapeutic options.

\subsection{Screening}

In individuals with MEN1, mortality rates associated with manifestations of the syndrome are as high as $50 \%$; the most common causes of death are sequelae of pancreatic endocrine tumors [37-40]; therefore, early screening is crucial. Children as young as age 5 can present with manifestations of MEN1, such as insulinomas [11,14,41]. MEN1 germline mutation testing should be offered to relatives of MEN1 patients, especially children and adolescents, even if relatives are asymptomatic. Individuals found to have a MEN1 germline mutation are recommended to undergo annual screening for MEN1-related tumors (Table 2). Annual screening for PHPT with plasma calcium and parathyroid hormone (PTH) is recommended. Screening for NETs, such as insulinomas and gastrinomas, should start at 5 years and 20 years of age, respectively. Imaging with MRI, CT, or endoscopic ultrasound are recommended, but recent advances have shown benefit in utilizing 68Ga dotatate PET/CT [42]. Pituitary adenomas are screened with annual serum prolactin and insulinlike growth factor-1 (IGF-1) and MRI every three years. Even after pituitary adenoma resection, it is suggested that screening continue as tumors may recur from residual tumor cells [43].

Table 2. Screening recommendations for MEN1 and MEN2.

\begin{tabular}{|c|c|c|c|}
\hline & Tumor & Age to Begin (Years) & Laboratory and Imaging \\
\hline \multirow[t]{4}{*}{ MEN 1} & Parathyroid adenoma & 8 & Calcium, PTH \\
\hline & Gastrinoma & 20 & Gastrin \\
\hline & Insulinoma & 5 & Fasting glucose and insulin \\
\hline & Pituitary adenoma & 5 & Prolactin, IGF-1, MRI \\
\hline MEN 2 & & & Genetic testing for RET \\
\hline \multirow[t]{3}{*}{ Type 2A } & MTC & $3-5$ & Calcitonin \\
\hline & Pheochromocytoma & 16 & Plasma/urine metanephrines and normetanephrines, CT or MRI \\
\hline & Parathyroid adenoma & 16 & Calcium, PTH \\
\hline \multirow[t]{2}{*}{ Type 2B } & MTC & 0.5 & Calcitonin \\
\hline & Pheochromocytoma & 11 & Plasma/urine metanephrines and normetanephrines, CT or MRI \\
\hline
\end{tabular}

PTH = parathyroid hormone; IGF-1 = insulin-like growth factor 1; MRI = magnetic resonance imaging; RET = REarranged during Transfection; MTC = medullary thyroid carcinoma; $\mathrm{CT}=$ computed tomography.

\subsection{Treatment}

The treatment of choice for parathyroid tumors is surgical resection $[9,14]$. The preferred timing and surgical approach of tumor resection is still debated in children and adolescents. In adults, surgical options include partial parathyroidectomy, subtotal parathyroidectomy (removal of 3.5 glands), or total parathyroidectomy with or without autotransplantation (transplantation of the remaining normal parathyroid tissue into the forearm) $[44,45]$. Post-surgical complications, such as permanent hypoparathyroidism and laryngeal nerve damage, can occur and are important to consider with respect to age and timing of surgery. Studies of MEN1-related PHPT are limited. However, studies have shown that children with non-MEN1 PHPT can be successfully treated by partial parathyroidectomy in the same manner as adults [46]. Persistent PHPT can affect the development of peak bone mass and can lead to osteoporosis and fragility fractures in adulthood $[47,48]$. Therefore, it has been suggested that adults have surgical intervention prior to the onset of symptoms or hypercalcemia in order to reduce the effects of unopposed parathyroid hormone hypersecretion [49]. Ultimately, providers must take into account the various considerations in pursuing parathyroid surgery, such as the presentation of 
symptomatic hypercalcemia, prevention of long-term consequences of unopposed PHPT, and the presence of gastrinoma. If concomitant endocrinopathies are present, parathyroidectomy is recommended to be completed first. However, if an active insulinoma is present, hypoglycemia must first be cured and parathyroidectomy must therefore be postponed [50,51].

Medical therapy is the preferred treatment for gastrinomas. $\mathrm{H}^{+}-\mathrm{K}^{+}$-adenosine triphosphatase inhibitors (i.e., omeprazole or lansoprazole) have been proven to be most effective for medical therapy [14]. Surgical therapy is ideally reserved for non-metastatic gastrinomas that are located within the pancreas and are larger than $2 \mathrm{~cm}$ as disease-related survival is reported to improve after surgery [52]. Other treatment modalities, such as chemotherapy, may be indicated in certain specific cases [53]. Tumors smaller than $2 \mathrm{~cm}$ have been found to have an excellent prognosis with medical management [54]. Overall, tumor size and the presence of hepatic metastases best determine the prognosis of MEN1 patients with gastrinomas. In $50 \%$ of patients, tumors can recur within 5 years after resection [55]. Therefore, long-term pediatric gastrinoma follow up is essential.

Surgical therapy is the treatment of choice for insulinomas, glucagonomas, and VIPomas $[2,14]$. Insulinomas require removal of a single tumor enucleation or partial pancreatectomy, and these surgical procedures have been quite successful, leading to minimal morbidity in children [56,57]. Preoperative and intraoperative localization, using preferred modalities of MRI and endoscopic ultrasound, is crucial in pediatric insulinoma management. Glucagonomas are most frequently found at the tail of the pancreas. Since 50 to $80 \%$ of glucagonomas have metastasized at time of diagnosis, surgical treatment may be unsuitable and patients may require treatment with somatostatin analogs or chemotherapy [58] VIPomas are also primarily located at the tail of the pancreas and surgical resection is curative [2,14].

Non-functioning NETs do not present with symptoms despite elevated hormone levels that are present biochemically. Nonetheless, they are considered potentially malignant. Surgery is not definitively recommended. However, tumor size can direct treatment decisions. In adults, tumors less than $2 \mathrm{~cm}$ are not recommended to undergo surgical resection [59]. A retrospective analysis found that there was no difference in overall survival when small tumors were observed versus surgically resected [60].

Pituitary tumors are treated both medically and surgically. In the case of prolactinomas, the most commonly presenting pituitary adenoma in MEN1 patients, first-line medical management includes the use of dopamine agonists. Dopamine agonists, such as cabergoline or bromocriptine, work to reduce tumor size and, in turn, normalize prolactin levels [61]. Resistance to medical therapy is defined as persistent hyperprolactinemia after three months of maximal treatment dosing and less than 50\% tumor shrinkage. In these resistant cases, the prolactinoma can be considered more aggressive [62]. Surgical intervention is thus indicated. Surgery is also reserved for neuro-ophthalmologic emergencies. Transsphenoidal surgery is considered first-line treatment $[14,63]$. Endonasal transsphenoidal endoscopic surgery (ETES) is also emerging as a surgical treatment option, especially in recurrent lesions [64]. Radiotherapy is reserved for unresectable tumors [14,65].

\section{Multiple Endocrine Neoplasia Type 2 (MEN2)}

MEN 2 is divided into two clinical subtypes: MEN2A and MEN2B. Familial medullary thyroid carcinoma (FMTC) is recognized as a variant of MEN2A. All types of MEN2 are due to a mutation in the RET gene. The estimated prevalence of MEN2-including MEN2A, MEN2B, FMTC, and other subtypes-is 1 in 30,000 [10]. It is important to note that genetic screening for MEN2 is highly disparate in different regions of the world; this heavily influences prevalence estimation by region [66]. While MEN2A and MEN2B are both characterized by medullary thyroid carcinoma (MTC) and pheochromocytoma (PHEO), clinical features and age of onset differ between the two forms. MTC is typically the first manifestation and is most aggressive. In all variants of MEN2, the lifetime risk of developing MTC is nearly 100\% [67]. 25\% of all identified MTC cases have been shown to 
be due to genetic causes, including MEN2 [10,68]. For this reason, guidelines recommend that all patients in whom MTC is identified receive routine genetic screening for RET mutations [69].

\subsection{MEN2A}

\subsubsection{Clinical Presentation}

MEN2A, also known as Sipple syndrome, has an estimated prevalence of 1 in 36,000 to 1 in 200,000 live births (Table 1) [70] with some countries, such as Denmark, noted to have a higher incidence of MEN2 due to founder effects within the population [71]. A diagnosis of MEN2A is made when a child has two or more of the following endocrine manifestations: MTC, PHEO, and/or PHPT [72].

MTC is typically the first manifestation of MEN2A and occurs in more than $90 \%$ of individuals [14]. The peak incidence of MTC in MEN2A patients is in the third decade of life [73]. In children, MTC may present before the age of 6, with some cases identified in children as young as 2 years of age [74]. MTC is a neuroendocrine tumor of the thyroid gland that presents as a proliferation of parafollicular C-cells, which secrete calcitonin. Unlike adults, children may not present with a neck mass at diagnosis, as diagnosis is frequently determined earlier than their clinical presentation by way of genetic testing. Nevertheless, signs and symptoms may include an anterior neck lump or symptoms related to an enlarged tumor, such as difficulty with breathing or swallowing, pain, or hoarseness. Elevated calcitonin levels on routine screening are also noted prior to the development of clinical symptoms [72]. However, calcitonin levels should be carefully interpreted. Clinicians should be aware that calcitonin levels are generally quite a bit higher in children under 3 years of age, especially in children under 6 months of age. Calcitonin levels are also higher in males as compared to females [75].

PHEO and PHPT more commonly present in adulthood. The development of the two tumors is significantly affected by the specific underlying RET gene mutation and mutation penetrance [75-77]. In adults, up to $50 \%$ of individuals with MEN2A present with PHEO in the second to third decade of life [78]. However, children as young as 8 years of age have presented with PHEO as well [79]. Symptoms may include headaches, flushing, diaphoresis, palpitations, tremors, nausea, and anxiety. PHEOs are generally nonmalignant. MEN2A-associated PHEOs are typically bilateral and isolated to the adrenal gland, rarely metastasizing [75]. The tumors can be diagnosed with elevated plasma or urinary metanephrine and normetanephrine levels [75].

PHPT occurs in 10-30\% of MEN2A patients and is generally mild, presenting as a benign adenoma or parathyroid hyperplasia $[78,80]$. The mean age of diagnosis is approximately 34 years, ranging from 12 to 70 years. However, children as young as 2 years have been diagnosed [81]. Often, individuals do not present with clinical symptoms. If symptomatic, an individual may clinically present with fatigue, polyuria, nausea, decreased appetite, or constipation due to hypercalcemia. Rarely has nephrolithiasis or osteitis fibrosa cystica been reported [81]. A laboratory evaluation may reveal a high or normal parathyroid hormone level in the setting of hypercalcemia.

Cutaneous lichen amyloidosis (CLA) is a rare dermatologic manifestation of MEN2A that presents as an intense pruritic rash that is classically found in the interscapular region. The rash improves with sun exposure and worsens with stress. The lesion may present at a young age prior to any clinically evident MTC $[82,83]$. The dermatologic condition has almost invariably been found in patients with a RET codon 634 mutation [84].

Hirschsprung disease is another condition that co-occurs with MEN2A [85]. The condition presents in infancy and newborns can present with constipation. Patients with Hirschsprung disease and an exon 10 RET mutation warrant further evaluation for MEN2A [75]. 


\subsubsection{Genetics}

MEN2 is due to a germline mutation of the RET proto-oncogene on chromosome $10 \mathrm{q} 11.2[67,86]$. The RET gene contains 21 exons and is $60 \mathrm{kB}$ in length [73]. This gene codes for a transmembrane tyrosine kinase, which was shown to be mutated in cases of both MEN2A and FMTC in 1993 [87]. The inciting mutation causes a gain of function within the translated protein, leading to a dysregulated cell cycle and oncogenesis [3]. In contrast with the MEN1 gene involved in MEN1, RET has a "hot spot" locus where mutations are more prevalent [12]. Unlike MEN1, MEN2 has a strong genotype-phenotype correlation, allowing for the main classifications of MEN2A and MEN2B, as well as their subtypes [88]. Genotype-phenotype correlation has been specifically noted in the case of PHEO risk, with specific codons of RET (634 and 918) being more frequently implicated [89]. Codon 634 has also been associated with an increased risk of CLA and PHPT in patients with MEN2A [76,81,90]. In patients with identifiable codon 634 mutations, the incidence of CLA is similar to the incidence of pheochromocytoma [83]. A cross-sectional genetic analysis of families with known MEN2A has shown that RET exons 10 and 11 are the most commonly implicated in syndromic pathogenesis [4]. More recent studies have furthered this analysis, showing that the most prevalent MEN2A-causative mutation lies in codon 634 within exon 11 [91]. FMTC is associated with germline mutations, which are found in $95 \%$ of families [10]. Many variations of RET mutations resulting in FMTC have been documented.

\subsection{Familial Medullary Thyroid Carcinoma (FMTC)}

Although FMTC was historically considered to be a distinct syndrome in which only increased risk for MTC occurred, the current concept of FMTC involves a MEN2A-FMTC spectrum, consisting of a phenotypic continuum involving progressively decreasing penetrance of PHEO and PHPT [3,75]. Using the information available due to the widespread increase in RET genetic screening, it has been suggested that up to $25 \%$ of all diagnosed MTC can be considered FMTC-related [10,73]. Diagnosis of FMTC typically occurs in the third to fourth decade of life, with a mean age of diagnosis of 34 [92,93]. There are strict clinical criteria that describe those with familial MTC: more than 10 family members with MTC, multiple carriers or affected members over 50 years of age, and an adequate medical history to exclude the presence of PHEO and PHPT [13]. Alternative diagnostic criteria describing the presence of at least four family members with MTC but without other manifestations of MEN2A has also been suggested [88,94]. Diagnosis may also occur via genetic testing that reveals a known FMTC-associated RET mutation [95]. The age of onset of MTC is typically late, appearing in the second or third decade of life. MTC associated with FMTC has a better prognosis than MTC associated with either MEN2A or MEN2B, and is also associated with better outcomes than sporadic MTC [3,92]. Distinguishing FMTC from MEN2A is challenging, especially since premature categorization of individuals in having FMTC can fail to identify individuals who may, in fact, later present with PHEO or PHPT. This concern further underscores the importance of correctly diagnosing familial MTC.

\section{3. $M E N 2 B$}

\subsubsection{Clinical Presentation}

MEN2B has a much lower prevalence than MEN2A, between 1 in 600,000 and 1 in $4,000,000$ depending on location (Table 1) [96,97]. Unlike MEN2A, children with MEN2B may present with additional clinical features apart from thyroid nodules. Features include marfanoid body habitus, mucosal neuromas (lips, tongue), eyelid eversion, prominent corneal nerves, and scoliosis. However, some of these features may not be clinically evident until several years of age [98,99]. In infancy, there may be earlier signs, such as alacrima and constipation, which can offer clues for early diagnosis [75]. Other clinical signs include decreased muscle tone, talipes equinovarus, and a failure to thrive with feeding difficulties [100].

Virtually all patients develop MTC, often before 1 year of age, much earlier than in individuals with MEN2A [101,102]. MTC is the leading cause of death in MEN2B. 
Unfortunately, phenotypic features often go unrecognized until late childhood because many patients carry de novo mutations. As such, individuals may present as adults when MTC is discovered. Therefore, tumor detection lag time rather than its invasive characteristics is suggested to be a reason for increased mortality in MEN2B $[3,100,103]$.

RET germline mutations in exon 16 codon M918T are the most common pathogenic variants associated with MTC, occurring in approximately $95 \%$ of patients [96]. The variant has an aggressive clinical presentation of MTC during childhood and can present in infancy $[75,104]$. As $25 \%$ of patients have hereditary MEN2B, the remaining $75 \%$ typically have de novo RET mutations and can present as phenotypically normal. As such, those with de novo mutations are more difficult to identify. Children with a de novo RET codon M918T mutation are more commonly diagnosed after detection of a thyroid nodule [105]. Individuals with MEN2B have a 50\% risk of developing PHEOs, which are benign tumors [100]. In children, PHEOs may develop as early as age 12 years with a mean age of about 15 years [106,107]. The tumors generally present earlier in MEN2B than in MEN2A and are more frequently bilateral in nature [108]. PHPT is not associated with MEN2B [101].

Ganglioneuromas of the gastrointestinal tract are rare tumors that present in up to $40 \%$ of individuals with MEN2B [105]. Patients may report symptoms of constipation, diarrhea, and bloating, and symptoms can begin as early as infancy or early childhood $[105,109]$.

\subsubsection{Genetics}

Like MEN2A, MEN2B is caused by a germline mutation within the RET gene that codes for a transmembrane tyrosine kinase [87]. However, while the most common mutation causing MEN2A is within codon 634, MEN2B is most often due to a mutation of codon 918 [91,97]. 95\% of identified cases worldwide have been most frequently due to a $\mathrm{M}$ to $\mathrm{T}$ substitution; $75 \%$ of these mutations occur de novo with the rest being inherited [96]. Most newly identified mutations are inherited paternally due to involvement of the RET protein in the renewal of spermatogonia [3]. Pathogenesis of MEN2B is similar to MEN2A, with dysfunctional protein leading to an unregulated cell cycle, causing an inborn predisposition to oncogenesis via constitutive intracellular kinase activation [110].

\subsection{MEN2 Screening}

Given that all children with MEN2B will develop MTC and particular RET codons may present with more aggressive MTC in children with MEN2A, screening and diagnosis is imperative in the prevention of metastatic MTC at an early age $[99,105,111]$. In their most recent MTC guidelines [75], the American Thyroid Association (ATA) stratified all known RET mutations into one of four risk levels to allow for better screening and treatment management: "highest risk" (HST), "high risk" (H), and "moderate risk" (MOD).

Children born to parents with MEN2B should obtain genetic testing for RET mutations. In cases where there is resistance to parental disclosure and child testing, legal intervention may be necessary as the child is at great risk for inheriting a malignant tumor [75]. Certain guidelines recommend that annual serum calcitonin screening should begin at age 6 months in children with MEN2B and age 3 to 5 years in those with MEN2A or history of FMTC [95]. Due to the early age of MTC onset, total thyroidectomy by 6 months of age is recommended in cases with confirmed MEN2B [97].

Individuals diagnosed with MEN2 are recommended to be screened annually for the presence of PHEO and PHPT even if asymptomatic (Table 2). Tumor screening should begin at age 11 for those with MEN2B and age 16 for those with MEN2A [75]. Although, the development of PHEO has been noted to develop at earlier ages [100]. Free plasma or 24-h metanephrines and normetanephrines are recommended for PHEO screening. If there is biochemical evidence of tumor, imaging with CT or MRI is then considered [75]. PHPT should be screened in those with MEN2A at the time of screening for PHEO, that is, by age 11 in those in the ATA "high risk" (ATA-H) category and by age 16 in those in the ATA "moderate risk" (ATA-MOD) ATA-high risk category [75]. 
Patients with MEN2A have a high risk of developing Hirschsprung's disease. As such, genetic screening in children with family history of Hirschsprung's disease is also recommended [112].

\subsection{MEN2 Treatment}

As DNA analysis has improved in recent decades, strong genotype-phenotype correlations have been established and have helped to facilitate guidelines for pediatric MEN2 treatment. Previously, calcitonin levels alone were used to determine candidacy for thyroidectomy. However, this led to some children being subjected to thyroidectomy when no RET mutation was identified by DNA analysis [113]. With DNA analysis, certain mutations have been determined to be more aggressive, especially in regards to MTC, and, therefore, specific treatment strategies have been recommended accordingly.

MTC is treated surgically. The goal is for the patient to undergo thyroidectomy before metastasis occurs, as MTC, at that point, is considered incurable and the most common cause of tumor death in individuals with MEN2A. Prophylactic thyroidectomy is defined as thyroid gland removal in children who have an inherited RET mutation. Those who do not undergo prophylactic thyroidectomy at an early age are more likely to develop metastatic MTC. The average survival expectancy in MEN2B carriers was approximately 21 years prior to the current, more standardized, recommendations for prophylactic thyroidectomy [99].

In children with MEN2A with a RET codon 634 mutation (ATA-H category), MTC develops in the first few years of life. Children are recommended to have annual physical examinations, thyroid ultrasounds, and serum calcitonin measurements starting at age $3[75,111]$. Children with mutations in the ATA-MOD category have similar screening recommendations but begin later at age 5; thyroidectomy in these patients is expected to occur in childhood or young adulthood depending on the serum calcitonin level. Despite prophylactic thyroidectomy, it is important to note that certain RET mutations appear to be associated with persistent or recurrent disease (i.e., codons 620 and 634) [102,114]. There are no generally accepted guidelines for basal or stimulated calcitonin levels in the development of C-cell hyperplasia. Levels are very high in the first months of life and decline to adult levels after 3 years of age [115]. Due to this phenomenon, it is recommended that providers become familiar with their own institution's calcitonin reference ranges [75].

With regards to MEN2B, MTC is usually highly aggressive and thus prophylactic thyroidectomy occurs much earlier in life. Those with known hereditary MEN2B are recommended to have a thyroidectomy in the first year of life, especially if they have a RET codon M918T mutation [97]. Thyroidectomy should be performed by an experienced surgeon in children, especially since the risk of hypoparathyroidism and subsequent hypocalcemia is higher $[45,75]$. If an experienced surgeon is not available, some suggest that thyroidectomy should be delayed to 2 years of age [116,117]. As surgical management can be challenging, parents known to be carriers for MEN2B mutations are encouraged to consider in vitro fertilization and preimplantation genetic diagnosis technologies [75].

If both MTC and PHEO are identified in a patient, the PHEO should be resected first given the significant morbidity and risk of stress-induced cardiovascular mortality $[75,97]$. To note, since PHEOs primarily occur later in adolescence, obtaining plasma or urine metanephrines and normetanephrines before prophylactic thyroidectomy is not indicated $[75,95]$.

The decision for bilateral or unilateral adrenalectomy depends upon the presence of bilateral or unilateral PHEOs, respectively, but also the risk for adrenal insufficiency. Individuals with solitary PHEO are recommended to have a unilateral adrenalectomy even though many will ultimately develop a contralateral PHEO [118]. The reason for this decision is based on the high risk for adrenal insufficiency after bilateral adrenalectomy. Laparoscopic adrenalectomy or retroperitoneoscopic adrenalectomy are the procedures of choice with no apparent difference in outcomes [119]. Adrenal-sparing surgery in bilateral PHEOs has also been shown to be successful and preferred if feasible and safe $[89,120]$. 
If total bilateral adrenalectomy is determined, it is imperative that individuals are given corticosteroid stress dosing perioperatively and postoperatively, as they will develop primary adrenal insufficiency [75,89]. Another consideration prior to adrenalectomy is the initiation of anti-hypertensive treatment with alpha and beta-adrenergic receptor blockade even if there is no evidence of biochemical abnormalities [13].

Surgical treatment for PHPT is similar to treatment in those with MEN1 as discussed earlier.

\section{Multiple Endocrine Neoplasia Type 4 (MEN4)}

MEN4 was first described in 2006 as an autosomal dominant disorder caused by germline loss of function in the cyclin-dependent kinase inhibitor 1B (CDKN1B) gene [5]. Despite its name, MEN4 is considered a variant of MEN1 [10]. It is an estimated 3\% of MEN1 cases and only 29 cases of MEN4 had been documented as of 2019, with 16 different underlying mutations [121,122]. Patients with MEN4 develop MEN1-associated tumors, although at a higher average age than in MEN1 [121]. The most common manifestation is parathyroid hyperplasia, which occurs in approximately $80 \%$ of patients (Table 1) [6]. Pituitary adenomas also occur but are typically smaller and less aggressive than MEN1related pituitary adenomas. The incidence of pancreatic neuroendocrine tumors is lower in MEN4 than in MEN1, with a penetrance of 20.6\% [31].

\section{Conclusions}

Multiple endocrine neoplasia (MEN) is a group of rare, heterogenous genetic disorders where two or more endocrine gland tumors occur in an individual or related individuals in the same family. The presentation of each disorder is variable and unique, and one must have a high index of suspicion to make the diagnosis, particularly in children. Our understanding of the clinical phenotypes and genetics of these conditions has grown significantly over the last several years, and guidelines have been developed for diagnosis and treatment of patients with MEN. Children diagnosed with one of the MEN syndromes require complex management and surveillance throughout their lifetime and should be referred to a tertiary care center with a multidisciplinary team of specialists.

Author Contributions: Conceptualization, M.J. and B.E.-L.; writing—original draft preparation, M.J., D.R., O.L. and B.E.-L.; writing-review and editing, M.J., D.R., O.L. and B.E.-L. All authors have read and agreed to the published version of the manuscript.

Funding: This research received no external funding.

Institutional Review Board Statement: Not applicable.

Informed Consent Statement: Not applicable.

Conflicts of Interest: The authors declare no conflict of interest.

\section{References}

1. Thakker, R.V. Multiple endocrine neoplasia type 1. Indian J. Endocrinol. Metab. 2012, 16, S272-S274. [CrossRef] [PubMed]

2. Thakker, R.V. Multiple endocrine neoplasia type 1. In Endocrinology; De Groot, L., Ed.; Elsevier: Philadelphia, PA, USA, 2010; pp. 2719-2741.

3. Raue, F.; Frank-Raue, K. Molecular Genetics of MEN2-Related Neuroendocrine Tumours. In Diagnostic and Therapeutic Nuclear Medicine for Neuroendocrine Tumors; Pacak, K., Taïeb, D., Eds.; Humana Press: Cham, Switzerland, 2017; pp. 65-81.

4. Mulligan, L.M.; Eng, C.; Healey, C.S.; Clayton, D.; Kwok, J.B.J.; Gardner, E.; Ponder, M.A.; Frilling, A.; Jackson, C.E.; Lehnert, H.; et al. Specific mutations of the RET proto-oncogene are related to disease phenotype in MEN 2A and FMTC. Nat. Genet. 1994, 6, 70-74. [CrossRef] [PubMed]

5. Pellegata, N.S.; Quintanilla-Martinez, L.; Siggelkow, H.; Samson, E.; Bink, K.; Höfler, H.; Fend, F.; Graw, J.; Atkinson, M.J. Germ-line mutations in p27Kip1 cause a multiple endocrine neoplasia syndrome in rats and humans. Proc. Natl. Acad. Sci. USA 2006, 103, 15558-15563. [CrossRef] [PubMed]

6. Alrezk, R.; Hannah-Shmouni, F.; Stratakis, C.A. MEN4 and CDKN1B mutations: The latest of the MEN syndromes. Endocr. Relat. Cancer 2017, 24, T195-T208. [CrossRef] [PubMed] 
7. Agarwal, S.K. The future: Genetics advances in MEN1 therapeutic approaches and management strategies. Endocr. Relat. Cancer 2017, 24, T119-T134. [CrossRef]

8. $\quad$ Brandi, M.L.; Agarwal, S.K.; Perrier, N.D.; Lines, K.E.; Valk, G.D.; Thakker, R.V. Multiple Endocrine Neoplasia Type 1: Latest Insights. Endocr. Rev. 2020, 42, 135. [CrossRef]

9. Marini, F.; Giusti, F.; Brandi, M.L. Multiple endocrine neoplasia type 1: Extensive analysis of a large database of Florentine patients. Orphanet J. Rare Dis. 2018, 13, 205. [CrossRef]

10. Romei, C.; Pardi, E.; Cetani, F.; Elisei, R. Genetic and clinical features of multiple endocrine neoplasia types 1 and 2. J. Oncol. 2012, 2012, 705036. [CrossRef]

11. Goudet, P.; Dalac, A.; Le Bras, M.; Cardot-Bauters, C.; Niccoli, P.; Lévy-Bohbot, N.; Du Boullay, H.; Bertagna, X.; Ruszniewski, P.; Borson-Chazot, F.; et al. MEN1 disease occurring before 21 years old: A 160-patient cohort study from the Groupe d'étude des Tumeurs Endocrines. J. Clin. Endocrinol. Metab. 2015, 100, 1568-1577. [CrossRef]

12. Falchetti, A. Genetics of multiple endocrine neoplasia type 1 syndrome: What's new and what's old. F1000Research 2017, 6, 73. [CrossRef]

13. Brandi, M.L.; Gagel, R.F.; Angeli, A.; Bilezikian, J.P.; Beck-Peccoz, P.; Bordi, C.; Conte-Devolx, B.; Falchetti, A.; Gheri, R.G.; Libroia, A.; et al. Guidelines for diagnosis and therapy of MEN type 1 and type 2. J. Clin. Endocrinol. Metab. 2001, 86, 5658-5671. [CrossRef] [PubMed]

14. Thakker, R.V.; Newey, P.J.; Walls, G.V.; Bilezikian, J.; Dralle, H.; Ebeling, P.R.; Melmed, S.; Sakurai, A.; Tonelli, F.; Brandi, M.L. Clinical practice guidelines for multiple endocrine neoplasia type 1 (MEN1). J. Clin. Endocrinol. Metab. 2012, 97, $2990-3011$. [CrossRef] [PubMed]

15. Eller-Vainicher, C.; Chiodini, I.; Battista, C.; Viti, R.; Mascia, M.L.; Massironi, S.; Peracchi, M.; D’Agruma, L.; Minisola, S.; Corbetta, S.; et al. Sporadic and MEN1-related primary hyperparathyroidism: Differences in clinical expression and severity. J. Bone Miner. Res. 2009, 24, 1404-1410. [CrossRef] [PubMed]

16. Vannucci, L.; Marini, F.; Giusti, F.; Ciuffi, S.; Tonelli, F.; Brandi, M.L. MEN1 in children and adolescents: Data from patients of a regional referral center for hereditary endocrine tumors. Endocrine 2018, 59, 438-448. [CrossRef] [PubMed]

17. Agarwal, S.K. Molecular Genetics of MEN1-Related Neuroendocrine Tumors. In Diagnostic and Therapeutic Nuclear Medicine for Neuroendocrine Tumors; Pacak, K., Taïeb, D., Eds.; Humana Press: Cham, Switzerland, 2017; pp. 47-64.

18. Krampitz, G.W.; Norton, J.A. Current management of the Zollinger-Ellison syndrome. Adv. Surg. 2013, 47, 59-79. [CrossRef] [PubMed]

19. Norton, J.A. Surgical treatment and prognosis of gastrinoma. Best Pract. Res. Clin. Gastroenterol. 2005, 19, 799-805. [CrossRef]

20. Gibril, F.; Schumann, M.; Pace, A.; Jensen, R.T. Multiple endocrine neoplasia type 1 and Zollinger-Ellison syndrome: A prospective study of 107 cases and comparison with 1009 cases from the literature. Medicine 2004, 83, 43-83. [CrossRef]

21. Ergun-Longmire, B.; Costi, G.; Maclaren, N. Multiple Endocrine Neoplasias. In Pediatric Endocrinology; Two Volume Set; Lifshitz, F., Ed.; Taylor \& Francis: Miami, FL, USA, 2007; pp. 617-635. ISBN -13:978-0849340680.

22. Lee, M.E.; Ortega-Sustache, Y.M.; Agarwal, S.K.; Tepede, A.; Welch, J.; Mandl, A.; Bansal, R.; Tirosh, A.; Piaggi, P.; Cochran, C.; et al. Patients with MEN1 Are at an Increased Risk for Venous Thromboembolism. J. Clin. Endocrinol. Metab. 2021, 106, E460-E468. [CrossRef]

23. Thomas-Marques, L.; Murat, A.; Delemer, B.; Penfornis, A.; Cardot-Bauters, C.; Baudin, E.; Niccoli-Sire, P.; Levoir, D.; Choplin, H.D.B.; Chabre, O.; et al. Prospective endoscopic ultrasonographic evaluation of the frequency of nonfunctioning pancreaticoduodenal endocrine tumors in patients with multiple endocrine neoplasia type 1. Am. J. Gastroenterol. 2006, 101, 266-273. [CrossRef]

24. Newey, P.J.; Jeyabalan, J.; Walls, G.V.; Christie, P.T.; Gleeson, F.V.; Gould, S.; Johnson, P.R.V.; Phillips, R.R.; Ryan, F.J.; Shine, B.; et al. Asymptomatic children with multiple endocrine neoplasia type 1 mutations may harbor nonfunctioning pancreatic neuroendocrine tumors. J. Clin. Endocrinol. Metab. 2009, 94, 3640-3646. [CrossRef]

25. Shariq, O.A.; Lines, K.E.; English, K.A.; Jafar-Mohammadi, B.; Prentice, P.; Casey, R.; Challis, B.G.; Selberherr, A.; Boon, H.; Cranston, T.; et al. Multiple endocrine neoplasia type 1 in children and adolescents: Clinical features and treatment outcomes. Surgery 2022, 171, 81. [CrossRef] [PubMed]

26. Stratakis, C.A.; Schussheim, D.H.; Freedman, S.M.; Keil, M.F.; Pack, S.D.; Agarwal, S.K.; Skarulis, M.C.; Weil, R.J.; Lubensky, I.A.; Zhuang, Z.; et al. Pituitary macroadenoma in a 5-year-old: An early expression of multiple endocrine neoplasia type 1. J. Clin. Endocrinol. Metab. 2000, 85, 4776-4780. [CrossRef] [PubMed]

27. Cuny, T.; Pertuit, M.; Sahnoun-Fathallah, M.; Daly, A.; Occhi, G.; Odou, M.F.; Tabarin, A.; Nunes, M.L.; Delemer, B.; Rohmer, V.; et al. Genetic analysis in young patients with sporadic pituitary macroadenomas: Besides AIP don't forget MEN1 genetic analysis. Eur. J. Endocrinol. 2013, 168, 533-541. [CrossRef] [PubMed]

28. Vergès, B.; Boureille, F.; Goudet, P.; Murat, A.; Beckers, A.; Sassolas, G.; Cougard, P.; Chambe, B.; Montvernay, C.; Calender, A. Pituitary disease in MEN type 1 (MEN1): Data from the France-Belgium MEN1 multicenter study. J. Clin. Endocrinol. Metab. 2002, 87, 457-465. [CrossRef]

29. Trouillas, J.; Labat-Moleur, F.; Sturm, N.; Kujas, M.; Heymann, M.F.; Figarella-Branger, D.; Patey, M.; Mazucca, M.; Decullier, E.; Vergès, B.; et al. Pituitary tumors and hyperplasia in multiple endocrine neoplasia type 1 syndrome (MEN1): A case-control study in a series of 77 patients versus 2509 non-MEN1 patients. Am. J. Surg. Pathol. 2008, 32, 534-543. [CrossRef] 
30. Lemos, M.C.; Thakker, R.V. Multiple endocrine neoplasia type 1 (MEN1): Analysis of 1336 mutations reported in the first decade following identification of the gene. Hum. Mutat. 2008, 29, 22-32. [CrossRef]

31. De Laat, J.M.; Van Leeuwaarde, R.S.; Valk, G.D. The Importance of an Early and Accurate MEN1 Diagnosis. Front. Endocrinol. 2018, 9, 533. [CrossRef]

32. De Laat, J.M.; van der Luijt, R.B.; Pieterman, C.R.C.; Oostveen, M.P.; Hermus, A.R.; Dekkers, O.M.; de Herder, W.W.; van der Horst-Schrivers, A.N.; Drent, M.L.; Bisschop, P.H.; et al. MEN1 redefined, a clinical comparison of mutation-positive and mutation-negative patients. BMC Med. 2016, 14, 1-7. [CrossRef]

33. Feng, Z.; Ma, J.; Hua, X. Epigenetic regulation by the menin pathway. Endocr. Relat. Cancer 2017, 24, T147-T159. [CrossRef]

34. Lu, Y.; Fei, X.Q.; Yang, S.F.; Xu, B.K.; Li, Y.Y. Glucose-induced microRNA-17 promotes pancreatic beta cell proliferation through down-regulation of Menin. Eur. Rev. Med. Pharmacol. Sci. 2015, 19, 624-629.

35. Luzi, E.; Ciuffi, S.; Marini, F.; Mavilia, C.; Galli, G.; Brandi, M.L. Analysis of differentially expressed microRNAs in MEN1 parathyroid adenomas. Am. J. Transl. Res. 2017, 9, 1743-1753. [PubMed]

36. Conemans, E.B.; Lodewijk, L.; Moelans, C.B.; Offerhaus, G.J.A.; Pieterman, C.R.C.; Morsink, F.H.; Dekkers, O.M.; De Herder, W.W.; Hermus, A.R.; Van Der Horst-Schrivers, A.N.; et al. DNA methylation profiling in MEN1-related pancreatic neuroendocrine tumors reveals a potential epigenetic target for treatment. Eur. J. Endocrinol. 2018, 179, 153-160. [CrossRef] [PubMed]

37. Goudet, P.; Murat, A.; Binquet, C.; Cardot-Bauters, C.; Costa, A.; Ruszniewski, P.; Niccoli, P.; Ménégaux, F.; Chabrier, G.; Borson-Chazot, F.; et al. Risk factors and causes of death in MEN1 disease. A GTE (Groupe d'Etude des Tumeurs Endocrines) cohort study among 758 patients. World J. Surg. 2010, 34, 249-255. [CrossRef] [PubMed]

38. Geerdink, E.A.M.; Van der Luijt, R.B.; Lips, C.J.M. Do patients with multiple endocrine neoplasia syndrome type 1 benefit from periodical screening? Eur. J. Endocrinol. 2003, 149, 577-582. [CrossRef] [PubMed]

39. Dean, P.G.; Van Heerden, J.A.; Farley, D.R.; Thompson, G.B.; Grant, C.S.; Harmsen, W.S.; Ilstrup, D.M. Are patients with multiple endocrine neoplasia type I prone to premature death? World J. Surg. 2000, 24, 1437-1441. [CrossRef] [PubMed]

40. Ito, T.; Igarashi, H.; Uehara, H.; Berna, M.J.; Jensen, R.T. Causes of death and prognostic factors in multiple endocrine neoplasia type 1: A prospective study: Comparison of 106 MEN1/Zollinger-Ellison syndrome patients with 1613 literature MEN1 patients with or without pancreatic endocrine tumors. Medicine 2013, 92, 135-181. [CrossRef] [PubMed]

41. Thakker, R. Multiple endocrine neoplasia type 1 (MEN1). In Translational Endocrinology and Metabolism; Robertson, R., Thakker, R., Eds.; The Endocrine Society: Chevy Chase, MD, USA, 2011; Volume 2, pp. 13-44.

42. Sadowski, S.M.; Millo, C.; Cottle-Delisle, C.; Merkel, R.; Yang, L.A.; Herscovitch, P.; Pacak, K.; Simonds, W.F.; Marx, S.J.; Kebebew, E. Results of (68)Gallium-DOTATATE PET/CT Scanning in Patients with Multiple Endocrine Neoplasia Type 1. J. Am. Coll. Surg. 2015, 221, 509-517. [CrossRef] [PubMed]

43. Schneider, D.F.; Mazeh, H.; Chen, H.; Sippel, R.S. Predictors of recurrence in primary hyperparathyroidism: An analysis of 1386 cases. Ann. Surg. 2014, 259, 563-568. [CrossRef]

44. Tonelli, F.; Marcucci, T.; Fratini, G.; Tommasi, M.S.; Falchetti, A.; Brandi, M.L. Is total parathyroidectomy the treatment of choice for hyperparathyroidism in multiple endocrine neoplasia type 1? Ann. Surg. 2007, 246, 1075-1082. [CrossRef]

45. Kiernan, C.M.; Grubbs, E.G. Surgical Management of Multiple Endocrine Neoplasia 1 and Multiple Endocrine Neoplasia 2. Surg. Clin. N. Am. 2019, 99, 693-709. [CrossRef]

46. Wang, W.; Kong, J.; Nie, M.; Jiang, Y.; Li, M.; Xia, W.; Meng, X.; Xing, X.; Wang, O. Primary hyperparathyroidism in Chinese children and adolescents: A single-centre experience at Peking Union Medical College Hospital. Clin. Endocrinol. 2017, 87, 865-873. [CrossRef] [PubMed]

47. Burgess, J.R.; David, R.; Greenaway, T.M.; Parameswaran, V.; Shepherd, J.J. Osteoporosis in multiple endocrine neoplasia type 1: Severity, clinical significance, relationship to primary hyperparathyroidism, and response to parathyroidectomy. Arch. Surg. 1999, 134, 1119-1123. [CrossRef] [PubMed]

48. Lourenço, D.M.; Coutinho, F.L.; Toledo, R.A.; Montenegro, F.L.; Correia-Deur, J.E.; Toledo, S.P. Early-onset, progressive, frequent, extensive, and severe bone mineral and renal complications in multiple endocrine neoplasia type 1-associated primary hyperparathyroidism. J. Bone Miner. Res. 2010, 25, 2382-2391. [CrossRef]

49. Lambert, L.A.; Shapiro, S.E.; Lee, J.E.; Perrier, N.D.; Truong, M.; Wallace, M.J.; Hoff, A.O.; Gagel, R.F.; Evans, D.B. Surgical treatment of hyperparathyroidism in patients with multiple endocrine neoplasia type 1. Arch. Surg. 2005, 140, 374-382. [CrossRef] [PubMed]

50. Marini, F.; Giusti, F.; Tonelli, F.; Brandi, M.L. When parathyroidectomy should be indicated or postponed in adolescents with MEN1-related primary hyperparathyroidism. Front. Endocrinol. 2018, 9, 597. [CrossRef] [PubMed]

51. Tonelli, F.; Giudici, F.; Cavalli, T.; Brandi, M.L. Surgical approach in patients with hyperparathyroidism in multiple endocrine neoplasia type 1: Total versus partial parathyroidectomy. Clinics 2012, 67, 155-160. [CrossRef]

52. Norton, J.A.; Jensen, R.T. Role of surgery in Zollinger-Ellison syndrome. J. Am. Coll. Surg. 2007, 205, S34-S37. [CrossRef] [PubMed]

53. Massaro, S.A.; Emre, S.H. Metastatic gastrinoma in a pediatric patient with Zollinger-Ellison syndrome. J. Pediatr. Hematol. Oncol. 2014, 36, e13-e15. [CrossRef]

54. Jensen, R.T.; Norton, J.A. Treatment of Pancreatic Neuroendocrine Tumors in Multiple Endocrine Neoplasia Type 1: Some Clarity but Continued Controversy. Pancreas 2017, 46, 589-594. [CrossRef] 
55. Nazir, Z. Long-term follow-up of a child with primary lymph node gastrinoma and Zollinger-Ellison syndrome. J. Pediatr. Surg. 2011, 46, 969-972. [CrossRef]

56. Peranteau, W.H.; Palladino, A.A.; Bhatti, T.R.; Becker, S.A.; States, L.J.; Stanley, C.A.; Adzick, N.S. The surgical management of insulinomas in children. J. Pediatr. Surg. 2013, 48, 2517-2524. [CrossRef] [PubMed]

57. Van Beek, D.J.; Nell, S.; Verkooijen, H.M.; Borel Rinkes, I.H.M.; Valk, G.D.; Vriens, M.R.; Goudet, P.; Vella, A.; Donegan, D.; Bartsch, D.K.; et al. Surgery for multiple endocrine neoplasia type 1-related insulinoma: Long-term outcomes in a large international cohort. Br. J. Surg. 2020, 107, 1489-1499. [CrossRef]

58. Åkerström, G.; Hellman, P. Surgery on neuroendocrine tumours. Best Pract. Res. Clin. Endocrinol. Metab. 2007, 21, 87-109. [CrossRef] [PubMed]

59. Triponez, F.; Goudet, P.; Dosseh, D.; Cougard, P.; Bauters, C.; Murat, A.; Cadiot, G.; Niccoli-Sire, P.; Calender, A.; Proye, C.A.G. Is surgery beneficial for MEN1 patients with small $(<\mathrm{or}=2 \mathrm{~cm})$, nonfunctioning pancreaticoduodenal endocrine tumor? An analysis of 65 patients from the GTE. World J. Surg. 2006, 30, 654-662. [CrossRef]

60. Sadot, E.; Reidy-Lagunes, D.L.; Tang, L.H.; Do, R.K.G.; Gonen, M.; D’Angelica, M.I.; DeMatteo, R.P.; Kingham, T.P.; Koerkamp, B.G.; Untch, B.R.; et al. Observation versus Resection for Small Asymptomatic Pancreatic Neuroendocrine Tumors: A Matched Case-Control Study. Ann. Surg. Oncol. 2016, 23, 1361-1370. [CrossRef] [PubMed]

61. Keil, M.F.; Stratakis, C.A. Pituitary tumors in childhood: Update of diagnosis, treatment and molecular genetics. Expert Rev. Neurother. 2008, 8, 563-574. [CrossRef] [PubMed]

62. Gonzaga, M.d.F.d.M.; de Castro, L.F.; Naves, L.A.; Mendonça, J.L.; Oton de Lima, B.; Kessler, I.; Casulari, L.A. Prolactinomas Resistant to Treatment with Dopamine Agonists: Long-Term Follow-Up of Six Cases. Front. Endocrinol. 2018, 9, 1-15. [CrossRef] [PubMed]

63. Kunwar, S.; Wilson, C.B. Pediatric pituitary adenomas. J. Clin. Endocrinol. Metab. 1999, 84, 4385-4389. [CrossRef]

64. Chivukula, S.; Koutourousiou, M.; Snyderman, C.H.; Fernandez-Miranda, J.C.; Gardner, P.A.; Tyler-Kabara, E.C. Endoscopic endonasal skull base surgery in the pediatric population. J. Neurosurg. Pediatr. 2013, 11, 227-241. [CrossRef] [PubMed]

65. Loeffler, J.S.; Shih, H.A. Radiation therapy in the management of pituitary adenomas. J. Clin. Endocrinol. Metab. 2011, 96, 1992-2003. [CrossRef]

66. Machens, A.; Lorenz, K.; Sekulla, C.; Höppner, W.; Frank-Raue, K.; Raue, F.; Dralle, H. Molecular epidemiology of multiple endocrine neoplasia 2: Implications for RET screening in the new millenium. Eur. J. Endocrinol. 2013, 168, 307-314. [CrossRef] [PubMed]

67. Wohllk, N.; Schweizer, H.; Erlic, Z.; Schmid, K.W.; Walz, M.K.; Raue, F.; Neumann, H.P.H. Multiple endocrine neoplasia type 2. Best Pract. Res. Clin. Endocrinol. Metab. 2010, 24, 371-387. [CrossRef] [PubMed]

68. Raue, F. German medullary thyroid carcinoma/multiple endocrine neoplasia registry. Langenbeck's Arch. Surg. 1998, 383, 334-336. [CrossRef]

69. Wohllk, N.; Cote, G.J.; Bugalho, M.M.; Ordonez, N.; Evans, D.B.; Goepfert, H.; Khorana, S.; Schultz, P.; Richards, C.S.; Gagel, R.F. Relevance of RET proto-oncogene mutations in sporadic medullary thyroid carcinoma. J. Clin. Endocrinol. Metab. 1996, 81, 3740-3745. [CrossRef] [PubMed]

70. Opsahl, E.M.; Brauckhoff, M.; Schlichting, E.; Helset, K.; Svartberg, J.; Brauckhoff, K.; Mæhle, L.; Engebretsen, L.F.; Sigstad, E.; Grøholt, K.K.; et al. A Nationwide Study of Multiple Endocrine Neoplasia Type 2A in Norway: Predictive and Prognostic Factors for the Clinical Course of Medullary Thyroid Carcinoma. Thyroid 2016, 26, 1225-1238. [CrossRef] [PubMed]

71. Mathiesen, J.S.; Kroustrup, J.P.; Vestergaard, P.; Stochholm, K.; Poulsen, P.L.; Rasmussen, Å.K.; Feldt-Rasmussen, U.; Schytte, S.; Pedersen, H.B.; Hahn, C.H.; et al. Incidence and prevalence of multiple endocrine neoplasia 2A in Denmark 1901-2014: A nationwide study. Clin. Epidemiol. 2018, 10, 1479-1487. [CrossRef] [PubMed]

72. Puñales, M.K.C.; Da Rocha, A.P.; Meotti, C.; Gross, J.L.; Maia, A.L. Clinical and oncological features of children and young adults with multiple endocrine neoplasia type 2A. Thyroid 2008, 18, 1261-1268. [CrossRef]

73. Nosé, V. Familial thyroid cancer: A review. Mod. Pathol. 2011, 24, S19-S33. [CrossRef]

74. Skinner, M.A.; DeBenedetti, M.K.; Moley, J.F.; Norton, J.A.; Wells, S.A. Medullary thyroid carcinoma in children with multiple endocrine neoplasia types 2A and 2B. J. Pediatr. Surg. 1996, 31, 177-182. [CrossRef]

75. Wells, S.A.; Asa, S.L.; Dralle, H.; Elisei, R.; Evans, D.B.; Gagel, R.F.; Lee, N.; MacHens, A.; Moley, J.F.; Pacini, F.; et al. Revised American thyroid association guidelines for the management of medullary thyroid carcinoma. Thyroid 2015, 25, 567-610. [CrossRef]

76. Imai, T.; Uchino, S.; Okamoto, T.; Suzuki, S.; Kosugi, S.; Kikumori, T.; Sakurai, A. High penetrance of pheochromocytoma in multiple endocrine neoplasia 2 caused by germ line RET codon 634 mutation in Japanese patients. Eur. J. Endocrinol. 2013, 168, 683-687. [CrossRef] [PubMed]

77. Frank-Raue, K.; Rybicki, L.A.; Erlic, Z.; Schweizer, H.; Winter, A.; Milos, I.; Toledo, S.P.A.; Toledo, R.A.; Tavares, M.R.; Alevizaki, M.; et al. Risk profiles and penetrance estimations in multiple endocrine neoplasia type $2 \mathrm{~A}$ caused by germline RET mutations located in exon 10. Hum. Mutat. 2011, 32, 51-58. [CrossRef] [PubMed]

78. Howe, J.R.; Norton, J.A.; Wells, S.A.J. Prevalence of pheochromocytoma and hyperparathyroidism in multiple endocrine neoplasia type 2A: Results of long-term follow-up. Surgery 1993, 114, 1070-1077. [PubMed]

79. Rowland, K.J.; Chernock, R.D.; Moley, J.F. Pheochromocytoma in an 8-year-old patient with multiple endocrine neoplasia type 2A: Implications for screening. J. Surg. Oncol. 2013, 108, 203-206. [CrossRef] 
80. Carling, T.; Udelsman, R. Parathyroid surgery in familial hyperparathyroid disorders. J. Intern. Med. 2005, 257, 27-37. [CrossRef] [PubMed]

81. Schuffenecker, I.; Virally-Monod, M.; Brohet, R.; Goldgar, D.; Conte-Devolx, B.; Leclerc, L.; Chabre, O.; Boneu, A.; Caron, J.; Houdent, C.; et al. Risk and penetrance of primary hyperparathyroidism in multiple endocrine neoplasia type 2A families with mutations at codon 634 of the RET proto-oncogene. Groupe D'etude des Tumeurs à Calcitonine. J. Clin. Endocrinol. Metab. 1998, 83, 487-491. [CrossRef] [PubMed]

82. Verga, U.; Fugazzola, L.; Cambiaghi, S.; Pritelli, C.; Alessi, E.; Cortelazzi, D.; Gangi, E.; Beck-Peccoz, P. Frequent association between MEN 2A and cutaneous lichen amyloidosis. Clin. Endocrinol. 2003, 59, 156-161. [CrossRef]

83. Gagel, R.F.; Levy, M.L.; Donovan, D.T.; Alford, B.R.; Wheeler, T.; Tschen, J.A. Multiple endocrine neoplasia type 2a associated with cutaneous lichen amyloidosis. Ann. Intern. Med. 1989, 111, 802-806. [CrossRef]

84. Rothberg, A.E.; Raymond, V.M.; Gruber, S.B.; Sisson, J. Familial medullary thyroid carcinoma associated with cutaneous lichen amyloidosis. Thyroid 2009, 19, 651-655. [CrossRef]

85. Verdy, M.; Weber, A.M.; Roy, C.C.; Morin, C.L.; Cadotte, M.; Brochu, P. Hirschsprung's disease in a family with multiple endocrine neoplasia type 2. J. Pediatr. Gastroenterol. Nutr. 1982, 1, 603-607. [CrossRef]

86. Takahashi, M.; Ritz, J.; Cooper, G.M. Activation of a novel human transforming gene, ret, by DNA rearrangement. Cell 1985, 42, 581-588. [CrossRef]

87. Donis-Keller, H.; Dou, S.; Chi, D.; Carlson, K.M.; Toshima, K.; Lairmore, T.C.; Howe, J.R.; Moley, J.F.; Goodfellow, P.; Wells, S.A. Mutations in the RET proto-oncogene are associated with MEN 2A and FMTC. Hum. Mol. Genet. 1993, 2, 851-856. [CrossRef] [PubMed]

88. Larouche, V.; Akirov, A.; Thomas, C.M.; Krzyzanowska, M.K.; Ezzat, S. A primer on the genetics of medullary thyroid cancer Curr. Oncol. 2019, 26, 389-394. [CrossRef] [PubMed]

89. Bryant, J.; Farmer, J.; Kessler, L.J.; Townsend, R.R.; Nathanson, K.L. Pheochromocytoma: The expanding genetic differential diagnosis. J. Natl. Cancer Inst. 2003, 95, 1196-1204. [CrossRef]

90. Ceccherini, I.; Romei, C.; Barone, V.; Pacini, F.; Martino, E.; Loviselli, A.; Pinchera, A.; Romeo, G. Identification of the Cys634-> Tyr mutation of the RET proto-oncogene in a pedigree with multiple endocrine neoplasia type 2A and localized cutaneous lichen amyloidosis. J. Endocrinol. Investig. 1994, 17, 201-204. [CrossRef] [PubMed]

91. Accardo, G.; Conzo, G.; Esposito, D.; Gambardella, C.; Mazzella, M.; Castaldo, F.; Di Donna, C.; Polistena, A.; Avenia, N.; Colantuoni, V.; et al. Genetics of medullary thyroid cancer: An overview. Int. J. Surg. 2017, 41, S2-S6. [CrossRef]

92. Saltiki, K.; Simeakis, G.; Anagnostou, E.; Zapanti, E.; Anastasiou, E.; Alevizaki, M. Different outcomes in sporadic versus familial medullary thyroid cancer. Head Neck 2019, 41, 154-161. [CrossRef]

93. Hyer, S.L.; Newbold, K.; Harmer, C. Familial medullary thyroid cancer: Clinical aspects and prognosis. Eur. J. Surg. Oncol. 2005, 31, 415-419. [CrossRef]

94. Eng, C.; Clayton, D.; Schuffenecker, I.; Lenoir, G.; Cote, G.; Gagel, R.F.; van Amstel, H.K.; Lips, C.J.; Nishisho, I.; Takai, S.I.; et al. The relationship between specific RET proto-oncogene mutations and disease phenotype in multiple endocrine neoplasia type 2. International RET mutation consortium analysis. JAMA 1996, 276, 1575-1579. [CrossRef]

95. Kloos, R.T.; Eng, C.; Evans, D.B.; Francis, G.L.; Gagel, R.F.; Gharib, H.; Moley, J.F.; Pacini, F.; Ringel, M.D.; Schlumberger, M.; et al Medullary thyroid cancer: Management guidelines of the American Thyroid Association. Thyroid 2009, 19, 565-612. [CrossRef]

96. Mathiesen, J.S.; Kroustrup, J.P.; Vestergaard, P.; Madsen, M.; Stochholm, K.; Poulsen, P.L.; Krogh Rasmussen, Å.; Feldt-Rasmussen, U.; Schytte, S.; Pedersen, H.B.; et al. Incidence and prevalence of multiple endocrine neoplasia 2B in Denmark: A nationwide study. Endocr. Relat. Cancer 2017, 24, L39-L42. [CrossRef] [PubMed]

97. Znaczko, A.; Donnelly, D.E.; Morrison, P.J. Epidemiology, Clinical Features, and Genetics of Multiple Endocrine Neoplasia Type 2B in a Complete Population. Oncologist 2014, 19, 1284-1286. [CrossRef] [PubMed]

98. Castinetti, F.; Moley, J.; Mulligan, L.; Waguespack, S.G. A comprehensive review on MEN2B. Endocr. Relat. Cancer 2018, 25, T29-T39. [CrossRef]

99. Moline, J.; Eng, C. Multiple endocrine neoplasia type 2: An overview. Genet. Med. 2011, 13, 755-764. [CrossRef] [PubMed]

100. Makri, A.; Akshintala, S.; Derse-Anthony, C.; Widemann, B.; Stratakis, C.A.; Glod, J.; Lodish, M. Multiple Endocrine Neoplasia Type 2B Presents Early in Childhood but Often Is Undiagnosed for Years. J. Pediatr. 2018, 203, 447-449. [CrossRef]

101. Brauckhoff, M.; Machens, A.; Hess, S.; Lorenz, K.; Gimm, O.; Brauckhoff, K.; Sekulla, C.; Dralle, H. Premonitory symptoms preceding metastatic medullary thyroid cancer in MEN 2B: An exploratory analysis. Surgery 2008, 144, 1044-1051. [CrossRef]

102. Skinner, M.A.; Moley, J.A.; Dilley, W.G.; Owzar, K.; DeBenedetti, M.K.; Wells, S.A. Prophylactic thyroidectomy in multiple endocrine neoplasia type 2A. N. Engl. J. Med. 2005, 353, 1105-1113. [CrossRef]

103. Voss, R.K.; Feng, L.; Lee, J.E.; Perrier, N.D.; Graham, P.H.; Hyde, S.M.; Nieves-Munoz, F.; Cabanillas, M.E.; Waguespack, S.G.; Cote, G.J.; et al. Medullary Thyroid Carcinoma in MEN2A: ATA Moderate- or High-Risk RET Mutations Do Not Predict Disease Aggressiveness. J. Clin. Endocrinol. Metab. 2017, 102, 2807-2813. [CrossRef]

104. Siqueira, D.R.; Ceolin, L.; Ferreira, C.V.; Romitti, M.; Maia, S.C.; Maciel, L.M.Z.; Maia, A.L. Role of RET genetic variants in MEN2-associated pheochromocytoma. Eur. J. Endocrinol. 2014, 170, 821-828. [CrossRef]

105. Wray, C.J.; Rich, T.A.; Waguespack, S.G.; Lee, J.E.; Perrier, N.D.; Evans, D.B. Failure to recognize multiple endocrine neoplasia 2B: More common than we think? Ann. Surg. Oncol. 2008, 15, 293-301. [CrossRef] 
106. Nguyen, L.; Niccoli-Sire, P.; Caron, P.; Bastie, D.; Maes, B.; Chabrier, G.; Chabre, O.; Rohmer, V.; Lecomte, P.; Henry, J.F.; et al. Pheochromocytoma in multiple endocrine neoplasia type 2: A prospective study. Eur. J. Endocrinol. 2001, 144, 37-44. [CrossRef] [PubMed]

107. Makri, A.; Akshintala, S.; Derse-Anthony, C.; Del Rivero, J.; Widemann, B.; Stratakis, C.A.; Glod, J.; Lodish, M. Pheochromocytoma in Children and Adolescents with Multiple Endocrine Neoplasia Type 2B. J. Clin. Endocrinol. Metab. 2019, 104, 7-12. [CrossRef] [PubMed]

108. Thosani, S.; Ayala-Ramirez, M.; Palmer, L.; Hu, M.I.; Rich, T.; Gagel, R.F.; Cote, G.; Waguespack, S.G.; Habra, M.A.; Jimenez, C. The characterization of pheochromocytoma and its impact on overall survival in multiple endocrine neoplasia type 2 . J. Clin. Endocrinol. Metab. 2013, 98, E1813-E1818. [CrossRef] [PubMed]

109. Cohen, M.S.; Phay, J.E.; Albinson, C.; DeBenedetti, M.K.; Skinner, M.A.; Lairmore, T.C.; Doherty, G.M.; Balfe, D.M.; Wells, S.A.; Moley, J.F. Gastrointestinal manifestations of multiple endocrine neoplasia type 2. Ann. Surg. 2002, 235, 648-655. [CrossRef] [PubMed]

110. Salvatore, D.; Melillo, R.M.; Monaco, C.; Visconti, R.; Fenzi, G.; Vecchio, G.; Fusco, A.; Santoro, M. Increased in vivo phosphorylation of ret tyrosine 1062 is a potential pathogenetic mechanism of multiple endocrine neoplasia type 2B. Cancer Res. 2001, 61, 1426-1431.

111. Machens, A.; Gimm, O.; Hinze, R.; Höppner, W.; Boehm, B.O.; Dralle, H. Genotype-phenotype correlations in hereditary medullary thyroid carcinoma: Oncological features and biochemical properties. J. Clin. Endocrinol. Metab. 2001, 86, 1104-1109. [CrossRef]

112. Decker, R.A.; Peacock, M.L. Occurrence of MEN 2a in familial Hirschsprung's disease: A new indication for genetic testing of the RET proto-oncogene. J. Pediatr. Surg. 1998, 33, 207-214. [CrossRef]

113. Lips, C.; Landsvater, R.M.; Hoppener, J.; Geerdink, R.A.; Blijham, G.; van Veen, J.M.J.-S.; van Gils, A.; de Wit, M.J.; Zewald, R.A.; Berends, M.; et al. Clinical screening as compared with DNA analysis in families with multiple endocrine neoplasia type 2A. N. Engl. J. Med. 1994, 331, 828-835. [CrossRef]

114. Frank-Raue, K.; Buhr, H.; Dralle, H.; Klar, E.; Senninger, N.; Weber, T.; Rondot, S.; Höppner, W.; Raue, F. Long-term outcome in 46 gene carriers of hereditary medullary thyroid carcinoma after prophylactic thyroidectomy: Impact of individual RET genotype. Eur. J. Endocrinol. 2006, 155, 229-236. [CrossRef]

115. Basuyau, J.P.; Mallet, E.; Leroy, M.; Brunelle, P. Reference intervals for serum calcitonin in men, women, and children. Clin. Chem. 2004, 50, 1828-1830. [CrossRef]

116. Sosa, J.A.; Tuggle, C.T.; Wang, T.S.; Thomas, D.C.; Boudourakis, L.; Rivkees, S.; Roman, S.A. Clinical and economic outcomes of thyroid and parathyroid surgery in children. J. Clin. Endocrinol. Metab. 2008, 93, 3058-3065. [CrossRef] [PubMed]

117. Tuggle, C.T.; Roman, S.A.; Wang, T.S.; Boudourakis, L.; Thomas, D.C.; Udelsman, R.; Ann Sosa, J. Pediatric endocrine surgery: Who is operating on our children? Surgery 2008, 144, 869-877. [CrossRef] [PubMed]

118. Asari, R.; Scheuba, C.; Kaczirek, K.; Niederle, B. Estimated risk of pheochromocytoma recurrence after adrenal-sparing surgery in patients with multiple endocrine neoplasia type 2A. Arch. Surg. 2006, 141, 1199-1205. [CrossRef]

119. Brunt, L.M.; Doherty, G.M.; Norton, J.A.; Soper, N.J.; Quasebarth, M.A.; Moley, J.F. Laparoscopic adrenalectomy compared to open adrenalectomy for benign adrenal neoplasms. J. Am. Coll. Surg. 1996, 183, 1-10.

120. Lee, J.E.; Curley, S.A.; Gagel, R.F.; Evans, D.B.; Hickey, R.C.; Pasieka, J.L.; Hamberger, B.; Thompson, N.W.; Danto, L.A Cortical-sparing adrenalectomy for patients with bilateral pheochromocytoma. Surgery 1996, 120, 1064-1071. [CrossRef]

121. Frederiksen, A.; Rossing, M.; Hermann, P.; Ejersted, C.; Thakker, R.V.; Frost, M. Clinical Features of Multiple Endocrine Neoplasia Type 4: Novel Pathogenic Variant and Review of Published Cases. J. Clin. Endocrinol. Metab. 2019, 104, 3637-3646. [CrossRef]

122. Ahmed, F.W.; Majeed, M.S.; Kirresh, O. Multiple Endocrine Neoplasias Type 4; StatPearls Publishing: Treasure Island, FL, USA, 2021; Bookshelf ID: NBK568728. 